\title{
THE INTEGRATION OF NAQLI AND AQLI KNOWLEDGE IN CURRICULUM AT UNIVERSITI SAINS ISLAM MALAYSIA: THE STUDY ON STUDENT'S INTERNSHIP ORGANIZATIONS IN KELANTAN, MALAYSIA
}

\author{
Mohamed Akhiruddin Ibrahim ${ }^{1 *}$, Mohammad Hikmat Shaker ${ }^{2}$, Shahirah Sulaiman ${ }^{3}$, \\ Azniwati Abdul Aziz ${ }^{4}$, Nur Safura Ab. Ghaffar ${ }^{5}$, Mohd Hisyamuddin Yusup ${ }^{6}$ \\ ${ }^{1}$ Senior Lecturer, Dr, Universiti Sains Islam Malaysia, MALAYSIA, akhiruddin@usim.edu.my \\ ${ }^{2}$ Senior Lecturer, Dr, London Open Academy, UNITED KINGDOM \\ ${ }^{3}$ Language Teacher, Universiti Sains Islam Malaysia, MALAYSIA \\ ${ }^{4}$ Language Teacher, Universiti Sains Islam Malaysia, MALAYSIA \\ ${ }^{5}$ Language Teacher, Universiti Sains Islam Malaysia, MALAYSIA \\ ${ }^{6}$ Student, Universiti Sains Islam Malaysia, MALAYSIA \\ ${ }^{*}$ Corresponding author
}

\begin{abstract}
The integration of Naqli and Aqli knowledge in curriculum has been a strategic plan of Universiti Sains Islam Malaysia to become a prominent global reference institution on its instigation by year 2025 . The university has introduced the term Naqli as divine knowledge; which it derives from Quran, Sunnah and references of respected books by previous religious scholars. While, the term Aqli denotes to modern knowledge that are gained through research and discoveries in the present. By having this integration in its curriculum on both of these disciplines, it has made Universiti Sains Islam Malaysia on its own as compared to other tertiary institutions. Through the integration; mandatory internship program for undergraduate students have embraced this curricular approach along with its students' industrial training session. The objectives for students to undergo the industrial training are for them to be familiarized with their potential job scopes, in addition, to practice the knowledge that they have learnt theoretically in the university. Students are required to choose any particular organization that has to do with their field of study, in order to gain experience and exposure in their upcoming working world. This study then intends to review the organizations that the Universiti Sains Islam Malaysia's students have attended for their industrial training session on the integration of both Naqli and Aqli practices. Particularly, this study will focus on the organizations in Kelantan as this is the state where majority of all the students are being sent to. This study discovers that regularly, students experience their internship in the state government departments; such as the Department of Islamic Religious Affairs, Kuala Krai Syariah Subordinate Court, Gua Musang Islamic Religious Office, Bachok Islamic Religious Office, Tanah Merah Islamic Religious Office and Kuala Krai Islamic Religious Affairs Office. Also, the students have attended their internship at federal government such as the Department of Indigenous (Orang Asli) Development, Kelantan State Education Department, Tumpat District Education Office and Machang District Education Office. They also underwent their internship in the local authorities'
\end{abstract}


offices such as Jeli District Council, non-governmental organizations such as the Muslim Youth Movement of Malaysia as well as private companies such as KEL Computer Station Sdn Bhd.

Keywords: Curriculum, Naqli and Aqli, Universiti Sains Islam Malaysia, internship, Kelantan.

\section{INTRODUCTION}

The internship for students in the Universiti Sains Islam Malaysia is integrated with the elements of 'Naqli' (Revelation Knowledge) and 'Aqli' (Human Knowledge) curriculum. Students have the freedom to choose any organization which is suitable with their field of study in order to undergo the internship. Most students from this university are known to originate from Kelantan, one of the east coast states in Malaysia, and a majority of them will undergo their internships where Kelantan being as their preferred state before ending their study. This article is written in order to examine the backgrounds of a few organizations chosen by the students from Kelantan and the activities held within the time frame of their internships.

\section{ORGANIZATIONS IN KELANTAN}

There are many organizations in Kelantan which are preferred by the students to undergo their internships as part of their university curriculum. These organizations are state government departments, federal government offices, non-governmental organizations, private companies, and local authorities' offices. The following are the names of the organizations; which are often preferred by to undergo their internships in Kelantan, as well as the students' Naqli and Aqli experiences:

\subsection{Kelantan Islamic Affairs Department}

Kelantan Islamic Affairs Department is an organization that contributes towards the Islamic process in the state of Kelantan. It has been established from 1979 until the period of reformation in 1998. This organization is established to spread Islam to the local community including the Muslims, Non-Muslims, staff from both government and private sector and Muslim converts. This department has organized various programs to propagate Islam to the Non-Muslims community in the state by running several talks and workshops. In addition, Islamic Legislation and state enactments have been enforced to those who deviate against Islamic practices.

The goal of this organization is to admin, manage, develop and expand the Islamic religious affairs in an efficient and effective manner to produce individuals who believe and please Allah in order to gain and maintain the safety and peace in Kelantan. Besides, this organization aims to develop and produce communities who are progressive in line with the state government policy, "Developing with Islam".

From the students' Naqli experience; they shared that daily (before the workers starts to commence their tasks); the staff, who are mostly amongst the male from this organization, will recite Quran verses along with its translation. The routine will be followed by Du'a recitation in seeking Allah's blessing for the day. Besides, every Thursday there will be a tazkirah session after Zuhur prayer. The tazkirah session is organized by the Dakwah Division discussing on religious matter referred from the Holy Quran and delivered by the respective invited speakers.

The objective of the program is to deliver more knowledge of Islam to the society as well as to Government agencies communities as well (Amalina, 2014). Besides organizing programs, the Dakwah division is also considered as the place for the converters to refer. A lot of people from other religions as Hindus, Buddhas and Christians came to the Dakwah Division to convert into Islam. As a result, the students who are the trainee; were given the responsibility to fill in the forms and to teach along the converts in reciting shahadah.

\subsection{Kuala Krai Syariah Subordinate Court}

Syariah Court of Kelantan State was led by Kelantan Senior Qadhi. Subsequently, it was under Syarie Chief Judge management since August 16th, 1998. Later, the Syariah Court is divided into four divisions, Division of Service Management and Financial, Syariah Appeal Court, Syariah High Court and Syariah Subordinate Court.

Kuala Krai Syariah Subordinate Court has been established in Section 8 (1), (2), (3) and (4) Enactment of Administration of Syariah Court in Kelantan since 1982 (Amendments 1998). Meanwhile, the establishment force was established on 16th July 1998 and was based on Gazette State of Kelantan Volume 51 Number 7 on the 26th of March 1998. 
Overall, from the industrial training Aqli perspectives, the students contributed and gave maximum effort to the organization. As an intern, the students were only given the administrative task as typing and photocopying the documents. Also, they had experience in dealing with clients at the service counter. In addition, they were assigned as typist to fill in the online registration and printing the decision letters after presiding process.

However, it was a bit challenging as the organization hires only six permanent staff and the students had been assigned for administrative tasks. Due to the shortage number of staff, the students faced a critical situation when they received an abundance of summon letters to be looked over at one time. The students managed to control the situation accordingly (Aisyah, 2015).

\subsection{Gua Musang Islamic Religious Office}

Gua Musang Islamic Religious Offices is located at Balai Raya Islam Gua Musang District, Kelantan. The vision of this department is to be an organization which can manage, arrange, develop and evolve Islam accordingly. The workers character is expected to be friendly with customers, as well as be prepared to explain the law and religious concerns to customers. In addition, they provide marriage certificate and 'enikah' cards to the customers. They will also process the approval form for clients to be wedded. Last but not least, they organize pre-marriage course every month.

On the Aqli industrial training routine; the students need to cater customers accordingly. However, if they cannot handle it, they will need to pass it to the officer in charge. In addition, they also need to check the approved marriage form. Furthermore, they need to register the data of married couple or 'Hasil'. A district Imam will bring the data of the married couple and hand it over to the Financial Officer before the officer later, handles it back to him. He has to record the data in the log book or they call it The Submission of Married Data (Abdul Fatah, 2015).

In addition, they have to produce marriage certificates, 'e-Nikah' cards and organize the pre-marriage course. For this event, they will usually be assigned as the master of ceremony of the ones who will be in charged for registration and certificates unit.

Meanwhile, on Naqli practices, impressively, the usual activity that the department does is reciting Al-Quran every morning at the meeting room. One person will recite Quran and then when he stops everyone will follow on which verse he has recited.

\subsection{Bachok Islamic Religious Office}

Bachok Islamic Religious Office was established in the 1940s. During the early establishment, it was known as Qadhi Bachok Court. After the Enactments of Islamic Family Law which was established in 1984, the court has been divided into two divisions; Syariah Subordinate Court and Qadhi Department. Bachok Islamic Religious Office is located in the district of Bachok, Kelantan. This office is located in an area that has three state government departments that includes Religion Department, Syariah Subordinate Court and District Council (MDB). The officer who is in charge in managing the office is Mr. Nik Ahmad Zuhdi Bin Nik Yaacob. $\mathrm{He}$ is also the supervisor for the trainees.

During the industrial training of Naqli and Aqli experience and activities, the students were placed at administration division. The department consists of two divisions named administration division and enforcement. The administration division has carried out a program called "Nurturing Youth's Iman" (Membina Remaja Iman (MRI)) entitled "The Beauty of Covering Aurat" (Kesempurnaan Menutup Aurat) that was held at Mosque Be'oh. The targeted participants for this program were boys aged between 13 to 17 years old. Ustaz Nik Ahmad Zuhdi Bin Nik Yaacob was the speaker for the talk while Haji Abdul Azziz Bin Abdul Kadiras was the Religious Officer.

The program was able to achieve its objective in spreading knowledge about aurat and on how to dress up accordingly in Islam. Moreover, the enforcement division had organized a motivational program for the society that involved pregnancy out of wedlock. These programs were held at the hall of Mahmoodi Mosque in Bachok. The objective of the program was to explain or expose to parents on the inheritance distribution to an illegitimate child in Islam. These programs had helped the trainee to enhance their communication and social skills appropriately (Raihan, 2014).

\subsection{Tanah Merah Islamic Religious Office}

Tanah Merah Islamic Religious Office was established on June 18, 1988 and was placed under the Islamic Affairs Department, headed by the Chief Assistant Director of Administration, of Islamic Family Law in the Head Office in Kota Bharu. The department is no longer under the control of Syariah Judiciary Department of 
Kelantan that was once known as the Senior Qadhi Court of Kelantan.

The vision of this department is to be an agency in administering, managing, developing and expanding Islamic affairs respectively as in line with their mission, "To help create a community that is progressive and based on Islamic moral standards in line with the vision of developing joint Islamic state by Islamic affairs management agencies efficiently and effectively". The Department of Religion's main scope is to manage the registration of marriage, divorce and Ruju' for Tanah Merah district and implement policies relating to the affairs of Islam and the enactment of regulations contained in the decision by the Kelantan state government and Kelantan Islamic Religious Council.

During the industrial training on Aqli experience; the students were assigned in managing the documents needed for marriage. Basically couples who wanted to get married must complete the documents needed like the form of the marriage and documents on HIV test. The completed documents need to be submitted to the Religion Department for approval from the organization. The completed data will be filled on the online form, 'E-Nikah'. Overall, the trainee learnt on the marriage documentation process and the management of forms appropriately (Ruhiyah, 2014).

\subsection{Kuala Krai Islamic Religious Affairs Office}

The Kelantan Islamic Affairs Department is located in Kota Bharu, Kelantan. The department was formally established on the 1st January, 1980. The purpose of this establishment is to help the Religion Departments of Kelantan and Malay Kelantan Customs in increasing the activities of preaching and developing Islamic affairs in Kelantan.

At the beginning of its establishment on 1st December 1950, the field work of Kelantan Islamic Affairs Department was known as Religious Supervisor Office. This department focuses on vies act prevention, arresting the Islamic offenders and criminal prosecution of the Muslims. The vision of this department is to become a leading agency that manages and develops the Islamic affairs in producing faithful Muslims in Islam. With this vision, this department refers to Islamic strategies in line with the policy of the Kelantan state, "Developing with Islam".

Apart from that, the department is looking up to create a prosperous and peaceful state; whereby the goal of this department is to develop, build and nurture the well-being of the community based on Islam through the planning and execution of strategic and effective strategies accordingly to Ahli Sunnah Wal Jamaah approach, as to ensure the sacredness of Islam is well-preserved.

On the Aqli scope of activities, the students spent almost 14 weeks in Administration and Dakwah section, Law and Family section and Enforcement section. The experiences that they gained were valuable and explicit as they have been exposed in executing and producing excellent outcomes towards their potential career path. Besides, the students were given the responsibility to deal with clients in processing the premarriage courses, marriage certificate, divorce certificate and counselling issues. Their communication and social skills were enhanced prominently as proper techniques in answering calls are very important in ensuring customers' satisfaction (Firdaus, 2014).

\subsection{Muslim Youth Movement of Malaysia (ABIM)}

The Muslim Youth Movement of Malaysia is a non-governmental organization (NGO). It is a missionary movement organization that nurtures knowledge which chooses to take an open approach on the reality of the local community while upholding the principles of Islam and the unity of knowledge, faith and charity in the course of human development. Although ABIM is addressing political issues at times, but it is always a non-partisan that does not favour any of the political parties.

The Secretariat of $A B I M$ is the main operation centre for $A B I M$ in Kelantan. Eight agencies involving management and education are operated under this secretariat that include Islamic Outreach ABIM (IOA), Al-Hikmah Islamic Primary School (SRI), Taski ABIM Kelantan, Kelantan Orphans Welfare Foundation (YAATIM), Complex Mosque of Al-Hikmah, Brigade Bakti of Kelantan state (BBMCK), Kelantan Islamic Student Mentor Association (PPIK) and Global Peace Mission (GPM). SRI and Taski ABIM are educational services institution. Particularly, Taski ABIM Kelantan is a preschool or early education for 4,5 and 6 years old children. This school has around 20 institutions in the Kelantan state.

In addition, the secretariat of ABIM in Kelantan state has also provided profusion of programs and activities on its own and collaboration with Islamic organizations like JAKIM, MAIK and LPPKN. Besides, Usrah Propagations, that is an Islamic study group, has been established by the encouragement and support from ABIM. From the abovementioned, the Aqli industrial training that has been provided by this secretariat has 
helped the Faculty of Quranic and Sunnah students in gaining resourceful knowledge and experiences. The students have applied the course that they have studied in Quranic and Sunnah studies into their training (Noramnah, 2014). The students were assigned as the financial assistant of the secretariat while some were responsible to manage and handle items for Taski in bookstore. The students were appointed as a temporary teacher at Al-Huda Tahfiz Center of ABIM for two months.

The lessons were delivered every Sunday to Thursday for two hours, at $3 \mathrm{pm}$ to $5 \mathrm{pm}$. At the same time, they also joined outdoor programs and activities along with the community round. During the practical months, they managed to get the experience of trip to the aboriginal place under the program involving Islamic Outreach ABIM Kelantan (IOA), Tamrin Sisma, and Smart Volunteer Program (Fatihah, 2015). After all, from the Naqli point of view, the vision of this department is to build and conduct civilization of "Khayra Ummah". Their mission for the society is to know and master the concept of Islamic approach in their life according to Al Quran and Sunnah.

\subsection{Kelantan Education Department}

The Kelantan Education Department has 5 district education offices namely; the Kota Bharu District Education Office, Pasir Mas and Tumpat District Education Office, Pasir Puteh and Bachok District Education Office, Tanah Merah, Machang and Jeli District Education Office and Kuala Krai/Gua Musang District Education Office. Subsequently, 2 more offices were added and there were 7 offices altogether that include the District Education Office of Kota Bharu, Pasir Mas, Tumpat, Pasir Puteh, Machang, Tanah Merah, Jeli, Kuala Krai and Gua Musang.

The vision of this department is to educate human quality by having proper education. Their mission is to preserve quality education system for potential aspiring individuals. The objective of this company is to produce dynamic, progressive and proactive leadership to implement holistic educational development and implement the education policy through the national education philosophy and implement the Education Development Master Plan (2011 - 2013).

On the Aqli industrial training; the students have worked on multiple tasks, projects and activities. The Islamic Education Sector has done so many programs and activities that can be divided into daily tasks that involve office work, and the outdoor activities that have to be conducted during the actual events. This sector was needed for helping the staff and other colleagues (Syafiqah, 2014). The students were also assigned to perform administrative tasks in completing and preparing the things needed to run any program. Despite of finishing administrative work, the students also participated in outdoor activities like attending meetings or Islamic leadership seminars.

\subsection{Tumpat District Education Office}

Tumpat District Education Office (PPDT) was established on 16 February 2008. PPDT is located approximately $0.8 \mathrm{~km}$ from Tumpat city and started operating officially in June 2008 after PPD Pasir Mas had authorized PPD Tumpat to manage on the exchange of students and teachers by its own. As the vision of this department is, "Quality Education Educated People Prosperous Nation"; the department is aiming to provide best education for the generations. The mission of this company is set as "Sustaining Quality Education System to Develop Individual Potential to Fulfill National Aspirations". The mission is to sustain the quality of education system in order to create potential individuals in accordance to the National's Aspiration. The department holds to the motto, which is "Wise, Transparency and Integrity".

On the Aqli industrial training; the students were placed under the supervisor, an officer of School Management Unit. All tasks must be carried out when instructed by the industrial supervisor. $\mathrm{Hj}$. Mat Razi bin Mat Ail also asked the students to help and perform the other officers' works (Husna, 2015). Most of the time, the students had been assigned by officers to key-in and organize the data and input, deal with customers as well as appointed as the registration secretariat for PPD Tumpat programs and activities. The sectors which they have been sent to are namely; Academic Management, School Management, Information and Technology Management, Development and Procurement Management, Quality Management and Services and Financial.

\subsection{Machang District Education Office}

The Machang District Education Office was fully operated on the 1st of April 2008. Previously known as PPD Tanah Merah-Machang-Jeli, the name of Machang District Education Department had subsequently changed to the administrative district and commonly known as PPD Pasir Puteh- Machang. Machang District Education Department is located at Sekolah Kebangsaan Tok Bok, Machang. 
PPD Machang sets its own vision, "Quality Education, Educated Mankind, Prosperous Country" which is to achieve quality education for the next generations in order to create a prosperous country. Meanwhile, the mission of this company is, "Perform Professional Services, Friendly and Quality to Meet the Aspiration of National Education Philosophy in Achieving Vision 2020". Last but not least, the motto of this company is, "Committed, Quality and Friendly". It aims to achieve the standard of excellence and empower the quality of leadership and management for schools, Machang PPD urged educators to improve the quality of teaching and learning in schools. Besides, the PPD aims to improve the friendly customer services and build good relations for all levels.

On Aqli industrial training experience; the students designated tasks at the Machang District Education Office which include all units, not merely focusing on the Islamic Education Unit. The units involved include Quality Assurance Unit, Finance and Account Unit, Psychology and Counseling Unit, School Improvement Partner Unit, Student Affairs Unit, Co-Curriculum Unit, and Sports Unit.

Their tasks were to manage all files for Al-Quran Recitation Event (Tilawah Al-Quran) and bring the files into the meeting room. They have to prepare the meeting room as well. Most of the tasks given to them were administrative work. For instance, distributing the files to all the members in the meeting and jotting down the minutes of meeting (Athiyyah, 2014). Furthermore, the administrative tasks included the collection of KWSP information and documents about the KAFA (Al-Quran dan Fardhu Ain class) teachers. It is compulsory for all schools under this organization to send the information of KAFA teachers' KWSP and BSN account number. All the information will be kept and arranged in a file before the staff can key in the data in the computer.

The students were responsible in managing all files needed for the judges and special officer involved in the event. The files will be distributed to each one of them according to their parts of judgments; including main judges, Tajwid judges, Tarannum judges, Fasohah judge, voice judge, program hosts, evaluators, and timekeeper.

\subsection{The Department of Indigenous (Orang Asli) Development}

The formation of Malaysia on 16th September 1963 has affected the Department of Indigenous' (Orang Asli) name to the name of the Department of Indigenous (Orang Asli) Affairs. On 14th January 2011, the launch of new names for the Department of Indigenous (Orang Asli) Affairs to the Department of Indigenous (Orang Asli) Development; as was officiated by YB Dato' Seri Haji Mohd Shafei bin Apdal, Minister of Rural and Regional Development at Equatorial Hotel, Cameron Highland, Pahang (Ministry of Rural and Regional Development, pp.16-17).

The administration of the Indigenous in Kelantan was created around the year 1953 or 1954 operating in $\mathrm{Kg}$. Bertam, Gua Musang. In 1959, the Indigenous Department (Orang Asli) was transferred to Kuala Krai. Later, the Department of Indigenous (Orang Asli) Development joined with the administration of Department of Indigenous (Orang Asli) Kelantan and Terengganu in 1982.

The vision of this department is to drive organizational excellence in the development of Indigenous (Orang Asli) communities on par with the public. Their mission is to implement inclusive development to enhance the socio-economic status and quality of life to the advancement of excellence in upholding the legacy of Indigenous (Orang Asli) people. The objective of this company is to expand the scope of exposure, infrastructure and social amenities to all the villages of Indigenous (Orang Asli) and improve the effectiveness of the organization by maintaining and embracing good governance.

During the four months of joining Kelantan and Terengganu Orang Asli Development Departments, from Aqli experience; the students were assigned in Indigenous (Orang Asli) Villages together with National Registration Department and Election Commission of Malaysia for a program called, "Documentation Program". The four days and three nights program gave the opportunity for the aboriginals to register officially with the Election Commission of Malaysia for their identity card registrations. The first location was Pos Pasik, followed by Kuala Wok and Pos Pulat. While on Naqli experience of industrial training; they went to Indigenous (Orang Asli)'s village in Kampung Kerbok to renovate the villager's mosque for two days and one night. The opportunity was used to teach the villagers to recite Al-Fatihah correctly (Aziani, 2015). Meanwhile, the children were taught to recite lqra'.

\subsection{KEL Computer Station Sdn. Bhd. (KCS)}

KEL Computer Station Sdn. Bhd. (KCS) was established on 18 April, 2001 under Mr Shahmi as the Chief Executive Officer. It is located at Kota Bharu, Kelantan. Within 13 years, KCS provides a broad range of Information Technology (IT) supports, including design, management, and deployment relevant to the 
business needs to reduce customer costs and increase customer competitiveness in today's global economy as to provide a reliable, cost effective, high quality technology, systems and services; that suits the interest of its customers, business partners, employees and community.

KCS strategic partnerships with leading IT providers allow them to leverage their customer business through high quality services and solutions. With KCS long-term commitment to the local Information Technology industry, they have successfully established themselves as a qualified and professional company, which specializes in ICT consulting, software applications and networking solutions. As KCS strives into the new millennium year, as the System Integrator, KCS provides a total solution including Network Installation, Hardware, Software Development, Training, Audio, Video, Contract Preventive Maintenance, CCTV Surveillance and Card Access System.

On Aqli industrial training experience; the students had undergone the training for 16 weeks. Their first task is to develop a company video profile. In addition, they had to add the information given and search for the suitable template in order to make the video simple yet interesting to watch. In addition, the students also need to update the website based on the clients' request (Husniah, 2016). This is in line with KCS's mission as to have a powerful team with the quality of each individual who is competitive, innovative and have a strong desire to ensure the success of the company. This is because KCS offers cost effective solutions, proven products, maintain gorging relationship with principals companies and excellent post-sales supports.

\subsection{Jeli District Council}

Jeli District Council was officially established on January 1, 1988 which is located in the town of Jeli, Kelantan. It continues to grow rapidly and ultimately aims to provide the best service to residents in terms of health and quality of life. All taxes that have been collected will be managed efficiently for financing development projects, services, maintenance of public facilities and planning the development of the district. The vision is set to become an independent local authority and able to provide the best services to customers by the year 2020 .

On Aqli industrial training experience, the students were assigned on administrative works. Instead of preparing the minutes of meetings, they were listed as well as one of the meeting board. Every details or issues which arouse in the meeting would be jotted down and reported. The trainee needs to learn and abide by the ethics in preparing the minutes of meeting. For instance, they had to follow the correct format and keep the confidentiality of the minutes of meeting (Amirul, 2015). Meanwhile, on Naqli practices, the meeting will be adjourned with the recitation of Tasbih Kaffarah and Al-'Asr surah.

\section{CONCLUSION}

According to the findings, majority of the students underwent their internships in governmental departments, especially those that are under the management of the states. Only a few students would choose to undergo their internships in non-government organizations. Since the number of students is quite high, their involvement with the local authorities is also minimal compared to governmental offices due to the limited number of placement in local authorities. Although there were a few students who underwent their internships in private companies, their number did not exceed those who were in governmental departments. Therefore it could be deduced that agencies and governmental departments, whether under the management of the state or federal government, had given a positive impact to the students of Universiti Sains Islam Malaysia in undergoing their internships.

\section{ACKNOWLEDGMENT}

This paper presentation is funded by Research Management Centre, Universiti Sains Islam Malaysia, Grant no. (PPP/USG-0115/FPQS/30/11415).

\section{REFERENCE LIST}

Bachok Islamic Religious Office, http://www.jaheaik.gov.my/v5/index.php/hubungi- kami/hubungipegawai/pejabat-agama-jajahan/bachok

E-Syariah official Portal, http://www.esyariah.gov.my/portal/page/portal/Portal\%20ESyariah\%20BM/Portal\%20ESyariah\%20Direktori\%20Mahkamah/Portal\%20ESyariah\%20Direktori\%20Kelantan 
Gua Musang Islamic Religious Office,

http://www.jaheaik.gov.my/v5/index.php/hubungi-kami/peta-lokasi/paj-gua-musang

KEL Computer Station Sdn. Bhd., http://kcs.com.my/2016/

Kelantan Education Department, http://jpnkelantan.moe.gov.my/v1

Kelantan Islamic Affairs Department, http://www.jaheaik.gov.my/v6/

Kelantan Syariah Judiciary Department, http://www.jksn.kelantan.gov.my/v2/index.php?lang=ms

Kuala Krai Islamic Religious Affairs Office,

http://www.jaheaik.gov.my/v5/index.php/hubungi-kami/hubungi-pegawai/pejabat-agama-jajahan/kualakrai

Ministry of Education Malaysia, Kelantan Education Department, http:/www.moe.gov.my/my/profiljabatan?div=31

Ministry of Rural and Regional Development, The Department of Indigenous (Orang Asli) Development Annual Report (2011)

Muslim Youth Movement of Malaysia, http://www.abim.org.my/profil/sejarah-abim.html

Tanah Merah Islamic Religious Office, http://www.jaheaik.gov.my/v5/index.php/hubungi-kami/hubungipegawai/pejabat-agama-jajahan/tanah-merah

\section{LIST OF STUDENTS (Interview)}

Abdul Fatah Abdul Ghani (2015), Student, Universiti Sains Islam Malaysia.

Ain Syafiqah Sarbin (2014), Student, Universiti Sains Islam Malaysia.

Amalina Ghazali (2014), Student, Universiti Sains Islam Malaysia.

Husna Mohd Yusoff (2015), Student, Universiti Sains Islam Malaysia.

Mohd Amirul Fahmi Mat Jusoh, (2015), Student, Universiti Sains Islam Malaysia.

Mohd Firdaus Mohd Baharuddin (2014), Student, Universiti Sains Islam Malaysia.

Nurul Fatihah Ahmad Kamil (2015), Student, Universiti Sains Islam Malaysia.

Raihan Mohd Sa`ud (2014), Student, Universiti Sains Islam Malaysia.

Ruhiyah Ayuni Che Kassim (2014), Student, Universiti Sains Islam Malaysia.

Siti Aisyah Kamaruddin (2015), Student, Universiti Sains Islam Malaysia.

Siti Husniah Zulkifli (2016), Student, Universiti Sains Islam Malaysia.

Siti Noramnah Mohd Sabri (2014), Student, Universiti Sains Islam Malaysia.

Siti Nor Athiyyah Mat Jusoh (2014), Student, Universiti Sains Islam Malaysia.

Wan Nur Aziani Wan Hassan (2015), Student, Universiti Sains Islam Malaysia. 